\title{
Research on the Training Mode of management professionals from the perspective of modern economy and Finance
}

\author{
Yuguo $\mathrm{Gao}^{1}$ \\ ${ }^{1}$ China University Of Geosciences, Wuhan, Wuhan, China
}

\begin{abstract}
With the continuous development of Chinese science, and the improvement of the comprehensive national strength in education, more and more attention has been paid to the university education opened different specialized subjects for the study of professional knowledge. With the development of The Times and economy, the study of a single professional discipline has been difficult to meet the needs of various positions, so each discipline should be crossed and integrated, actively respond to the call of the state to innovate and train new talents, adapt to the national development.
\end{abstract}

\section{Introduction}

The study of single subject knowledge in college education cannot meet the requirements of various positions today. Therefore, colleges and universities should actively respond to the call of the state, optimize the layout of various disciplines, encourage the discovery of new crossdisciplines, and train new talents in the future. Modern politics, on the other hand, seems to have nothing to do with finance and management. This article through to develop a new form of a cross subject, the significance of the modern economy and the relationship and difference between financial and management disciplines, cultivate the modern economic and financial discipline and the method of strategy management discipline talents, these three aspects, to the modern economic and financial perspective to analyze research and professional talent training mode of management [1].

\section{The significance of cultivating new interdisciplinary subjects}

Countries for the cultivation of professional talents in colleges and universities have a set of complete system, each has different college professional colleges and universities, according to different specialty, of course education is different also, to the cultivation of professional talent is that in order to make the students after graduation can have better professional knowledge can play on the post, with their own professional knowledge contribute to the nation. In recent years, with the rapid development of China's economy, breakthroughs have been made in various fields and brilliant achievements have been made. However, the requirements for post talents are getting higher and higher, and only master a single professional knowledge is not competent for most posts. The current electricity industry rapid development, for example, electricity professional's too hot in recent years, but the development of electrical business also needs to logistics management, payment security, distribution, and so on several aspects to complete, if only, if only single learn knowledge network operation, but don't know the logistics process, also be the work of electricity industry. Therefore, a variety of different disciplines are required to be crossintegrated to encourage students to learn and cultivate new cross-disciplines. As early as 2003, Zhejiang University put forward the strategy of "speeding up the optimized layout of disciplines, vigorously supporting and cultivating new cross-disciplines", which has been well implemented and improved, and has cultivated a large number of outstanding talents for the country [2]. Position requirements better through their own professional knowledge to contribute to the nation, and the implementation of the scheme also improves students' learning ability and the personal level, satisfy the demand, also improve the ability of individuals, better contribute to national development, the significance of this is to develop a new interdisciplinary.

\section{Connections and differences between modern economics and finance and management}

\subsection{The relationship between modern economics and Finance and management}

Finance and management are both popular majors in colleges and universities. The table 1 shows the universities in 2018 and the popular majors. It can be seen from the chart that economics and management are both popular majors with more people paying attention to them [3]. 
Table1. Popular professional charts

\begin{tabular}{|c|c|c|c|}
\hline $\begin{array}{c}\text { Serial } \\
\text { number }\end{array}$ & $\begin{array}{c}\text { professional } \\
\text { title }\end{array}$ & $\begin{array}{c}\text { Professional } \\
\text { category }\end{array}$ & Followers \\
\hline 1 & finance & economics & 2962490 \\
\hline 2 & $\begin{array}{c}\text { civil } \\
\text { Engineering }\end{array}$ & engineering & 2514761 \\
\hline 3 & $\begin{array}{c}\text { international } \\
\text { economy and } \\
\text { trading }\end{array}$ & economics & 2410988 \\
\hline 4 & Machine made & engineering & 2187583 \\
\hline 5 & Accounting & management & 2023335 \\
\hline 6 & economics & economics & 1943351 \\
\hline 7 & $\begin{array}{c}\text { Electrical } \\
\text { engineering }\end{array}$ & engineering & 1920528 \\
\hline 8 & $\begin{array}{c}\text { Clinical } \\
\text { medicine }\end{array}$ & medicine & 1578737 \\
\hline 9 & Law & law & 1528571 \\
\hline 10 & English & English & 1488599 \\
\hline
\end{tabular}

Economics and finance is a subject developed in colleges and universities. Its main content is to learn and understand the knowledge of finance and cultivate outstanding talents for the future development of the financial industry. The significance of finance is to study the effective allocation of financial resources and to allocate and manage resources reasonably. With the rapid development of the national economy, finance is also a hot subject at present [4]. However, the awareness of finance can effectively allocate and manage financial resources, which also involves the content and knowledge of management. Management is a business major, whose main purpose is to be applied in future work practice. The significance of management is that managers in a team make overall layout through coordination, organization, control and other behaviors, so as to achieve established goals and make reasonable planning for the layout and development of things. However, in management, as a manager, the planning and layout of things also includes the contents of economics such as salary and capital investment. Therefore, from the definition of economy and finance and management can be seen in the modern economy is closely connected with the connection between the financial and management disciplines, although they are two unrelated subjects, but there are links between them, there are interdependent, mutually to have management content in economics, and economic class will also be involved in the management of knowledge, if a student only study the economic content of a single, not reasonable management for things, so he is not up to the requirements of economic and financial position; If a student only pays attention to the study of economics and ignores the role of finance, he will not achieve great success. Therefore, modern economics and finance are closely related to management. This is also one of the reasons why we should conduct interdisciplinary study. Only through interdisciplinary study can we master a variety of professional knowledge to better fit for the post and adapt to the development of the country and The Times [5].

\subsection{The difference between modern economics and finance and management}

Economy and finance originate from the emergence of money. Money is the earliest exchange of goods. It is not seen that goods are exchanged through money. So the origins of finance have a long history. Finance has been brewing and developing since the beginning of currency.

The origin theory of management is a series of measures put forward by Taylor in the 18th century to improve production efficiency. Thus, it can be seen that the history of the origin of management is not long compared with that of finance, and the system is not perfect compared with finance. Managers are for the purpose of improving the economic level and obtaining more wealth, while management is for the purpose of improving production efficiency and promoting the rapid development of things. Their emphasis is different, and their content and development history are also quite different. There is a significant difference between the financial discipline, which focuses on the development of economy, and the management discipline, which focuses on the improvement of the efficiency of things.

Modern economics and finance disciplines are significantly different from and closely related to management disciplines. There are knowledge of management in finance and content of finance in management. Therefore, in order to better cultivate new talents, the two disciplines should be cross-studied. Therefore, students should study management from the perspective of modern finance and economics. In this way, students can understand certain financial knowledge, and in the study of management, they can better improve their personal ability to meet the needs of management positions in the contemporary society with financial thinking.

The following figure shows the majors of Chinese students studying abroad. It can be seen from the figure that the proportion of economics and management is the largest, which also proves the connection between economic management and the popularity of economics and management.

With the development of society, my country's economic level has reached a certain height, and at the same time, it has formed a complex economic relationship system that can not be analyzed by the human brain. Economic statistics require advanced technology and efficient data processing methods, and the application of modern statistical analysis technology has become an inevitable development of the times.

The application of data mining technology to talent training in the field of higher education in China is reviewed. Based on the introduction of the basic principles of classic mining algorithms, it summarizes the characteristics and deficiencies of its application in talent training in colleges and universities, and based on the development trend of education informatization, gives the areas to focus on in the future. The mining algorithms involved include association rules, cluster analysis, 
decision trees, attribute reduction, support vector machines and other widely used technologies. The above work can be used to train talents in colleges and universities in China Provide useful references for management decisions. Data mining is a hot issue in the field of artificial intelligence and database research. The so-called data mining refers to the non-trivial process of revealing hidden, previously unknown and potentially valuable information from a large amount of data in the database. Data mining is a decision support process, which is mainly based on artificial intelligence, machine learning, pattern recognition, statistics, database, visualization technology, etc., highly automated analysis of enterprise data, make inductive reasoning, and mine potential patterns from it To help decision makers adjust market strategies, reduce risks, and make correct decisions.

Data mining is a technique to find the law from a large amount of data by analyzing each data. There are three steps: data preparation, law search and law expression. Data preparation is to select the required data from the relevant data sources and integrate them into a data set for data mining; law search is to find out the rules contained in the data set by some method; law expression is to use the user as much as possible. The way of understanding expresses the found rules. Data mining tasks include association analysis, cluster analysis, classification analysis, anomaly analysis, specific group analysis and evolution analysis.

In recent years, data mining has attracted great attention from the information industry. The main reason is that there is a large amount of data, which can be widely used, and there is an urgent need to convert these data into useful information and knowledge. The acquired information and knowledge can be widely used in various applications, including business management, production control, market analysis, engineering design and scientific exploration. The use of data mining technology also plays a huge role in the training of economic talents.

\section{Strategies for cultivating managerial talents from the perspective of modern economics and finance}

\subsection{Improve the teaching system and offer economics courses in management}

In order to train managerial talents from the perspective of modern economics and finance, we should first improve the teaching system, formulate a series of teaching plans for the training of new cross-disciplines, and constantly improve them to form a complete teaching system. In order to train managerial talents from the perspective of economy, it is necessary to set up courses of economics in the teaching courses of management. In the course of learning, knowledge of management and economics will be interspersed to better learn and understand. With the foundation of economic knowledge, management students will better analyze and predict some management cases. So as to improve the students' personal ability and management level, for the future work development laid a good foundation [6].

\subsection{Change the ideological content of single teaching and combine finance with management}

To want to modern economic and financial perspective management discipline talents cultivation, the first thing to change the traditional teaching ideas, change single teaching methods, to make a shift in thinking, to accept the interdisciplinarity learning, ideological to combining financial and management disciplines, ideological change of financial and management disciplines, change single teaching methods and teaching thoughts, promote the continuous development of new teaching ideas. Accept the teaching and arrangement of new interdisciplinary courses, accept the interdisciplinary study of a certain discipline from the perspective of thinking, combine finance and management, train professional managers from the perspective of finance, and better improve students' management ability and level [7].

\subsection{Pay attention to teaching quality and practice}

The study of any course needs to pay attention to the teaching quality, while the management discipline is a business discipline. The study of management and discipline can lay a better foundation for the future work. Therefore, under the modern economic and financial perspective to develop professional management talents, needs to attach importance to the quality of teaching, pay attention to practice, can not only learn the theoretical knowledge, as is known to all, college of management, economics, the focus on content, subject knowledge is also different, management students to learn the theoretical knowledge of economics, the economics knowledge to understand, [8] so should pay attention to the practice in the management of teaching content, through practice to let the students better understand the connection between the management and economics, well, more clear, quick understanding of the simple content of economics, and economics knowledge and management knowledge to achieve mastery through a comprehensive, Better use in the future management methods [9]. Therefore under the economic perspective, management the cultivation of professional talents, more important is to pay attention to practice, learning theory knowledge is not only good to improve management ability and level of students, should pay attention to the practice, in practice, a better understanding of the complex content of economics, and better use of the content of the economics to the management. In this way, management talents can be better cultivated from the perspective of modern economics and finance [10].

\section{Conclusion}

Modern economics and finance are inextricably linked. Cultivating management talents from a modern economic and financial perspective is also a direction for future management development. It is necessary to integrate the 
knowledge and content of economics in management, so that students can better integrate the knowledge of the two disciplines into the content of better learning management, so as to improve the personal learning ability and level of students and lay a solid foundation for future work. Through their own efforts, they will contribute to the development of the country in their own posts. [11]

\section{Reference}

1. Luo Feng, Yang Wangcheng, Wu Cairong, Exploration of Management Course Teaching Reform based on application-oriented Innovative Talent Training [J. University Education, 2018(12)

2. Xiao Linsheng. Teaching Reform of Management Course with Ability Cultivation as the core]. Guangdong Vocational And Technical Education and Research, 2017(02)

3. Sun Jing. Research on the Application of Flipped Classroom Teaching Model in Management Teaching [J], Tomorrow Fashion, 2017(03)

4. Yu Ting, Li Changwei. A Study on the Training Mode of Management Professionals from the Perspective of Foreman Integration[J]. Modern Marketing (Business Edition), 2018, No.308(08):28.

5. Zeng Qi. Research on the "Management with Work" Talent Training Model of Business Administration Major Based on the Perspective of Internet Innovation and Entrepreneurship[J]. Education and Teaching Forum, 2019, 410(16):27-28.

6. Zhang Li. Research on the training model of business management professionals based on innovation and entrepreneurship education[J]. China Real Estate Industry, 2018, 000(016):P.253-253.

7. Fang Jianhong. Analysis on the training model of business management professionals based on innovation and entrepreneurship education[J]. Education, 2016(12):00258-00258.

8. Zhang Peng. Research on the practical teaching model of the cultivation of innovative entrepreneurial talents in the field of business management[J]. Science Teaching Journal (Mid-Term), 2018, 353(10):50-51.

9. Duan Chao. Discussion on the training model of entrepreneurial and innovative talents in business administration majors in universities[J]. Foreign Trade, 2018, 000(001):P.155-157.

10. Zhang Li. A Study on the Training Mode of Innovative and Entrepreneurial Talents in Key Professional Groups in Business Administration[J]. Foreign Trade, 2014.

11. Zhang Li, Wang Limin, Wei Shasha. Research on the Construction of Business Management Professional Group Based on the Cultivation of Innovation and Entrepreneurship Ability $[\mathrm{J}]$. Chinese Commercial Forum, 2018, 000(001):P.174-175. 